http://dx.doi.org/10.11646/phytotaxa.142.1.8

\title{
Smilax jiankunii, a new synonym in Chinese Smilax (Liliales: Smilacaceae)
}

\author{
ZHECHEN QI ${ }^{1,2}$, PAN LI $^{3}$, YUJUAN DU ${ }^{4}$ \& CHENGXIN FU ${ }^{1, *}$ \\ ${ }^{I}$ The Key Laboratory of Conservation Biology for Endangered Wildlife of the Ministry of Education, and Laboratory of Systematic \& \\ Evolutionary Botany and Biodiversity, College of Life Sciences, Zhejiang University, Hangzhou 310058, China \\ ${ }^{2}$ Present address: College of Life Sciences, Zhejiang Sci-Tech University, Hangzhou 310018, China \\ ${ }^{3}$ Research \& Development Centre, Firmenich Aromatics (China), Shanghai 201108, China \\ ${ }^{4}$ Patent Examination Cooperation Jiangsu Center of the Patent Office, SIPO, Suzhou 215011, China \\ *Author for correspondence, email: cxfu@zju.edu.cn
}

Smilax Linnaeus (1753: 1028), the only genus of Smilacaceae, consists of over 200 species (with ca. 90 in China), and is widely distributed from tropical to temperate areas (Qi et al. 2012). Li (1992: 21) published Smilax jiankunii H.Li, based on specimens collected in the Dulongjiang Valley, Gongshan County, northwestern Yunnan Province, China. Smilax jiankunii was characterized by having a smooth stem, abaxially glaucous leaves, slender peduncles 9 to $10 \mathrm{~cm}$ long, densely flowered umbels (with 60-100 flowers), and the whole plant becoming blackish when dried (Li 1992), a feature shared with Smilax pottingeri Prain (1900: 174). Since Wang \& Tang (1978) transferred S. pottingeri to the genus Heterosmilax Kunth (1850: 270) as $H$. pottingeri (Prain) Wang \& Tang (1978: 245), based on the leaf shape and flattened peduncles, it is understandable that Li failed to compare her new species with it at that time. However, the name Smilax pottingeri was more recently accepted under Smilax again, due to more collections and knowledge of this plant becoming available (Chen \& Koyama 2000), and the genus Heterosmilax having been merged with Smilax based on morphological and molecular studies (Judd 1998, Cameron \& Fu 2006, Qi et al. 2012, 2013). After comparing the descriptions of both, we recognized that Smilax pottingeri appears to be similar to $S$. jiankunii, which has smooth stems, abaxially glaucous leaves, a slender peduncle 3 to $6 \mathrm{~cm}$ long and densely flowered umbels (with 40-70 flowers), but a more southern distribution in eastern Myanmar, southeastern Yunnan, Vietnam, northern Laos and northern Thailand (Koyama 1975, Chen \& Koyama 2000, Nguyên 2007).

We therefore examined the type specimens of $S$. jiankunii and S. pottingeri, as well as living plants, and found them to be identical. DNA barcoding markers ( $m a t K, r b c L)$ of the two were also analyzed to test the species boundaries. The results showed that $S$. jiankunii was within the range of morphological and genetic variation of $S$. pottingeri (Qi et al., unpublished data). Moreover, we simulated the potential distribution of $S$. pottingeri based on specimen occurrence (Fig. 1) with the ecological niche modeling method of Elith et al. (2011) and found Smilax jiankunii to be within the predicted distribution range of S. pottingeri, which further supported recognition of only a single species. Therefore, we here propose $S$. jiankunii as a synonym of $S$. pottingeri.

Smilax pottingeri Prain (1900: 174) = Heterosmilax pottingeri (Prain) Wang \& Tang (1978: 245). Lectotype (designated by Koyama 1983: 76):-MYANMAR. Kachin: Myaungjong, 12 June 1897, Pottinger s.n. (K!). Syntype:MYANMAR. Kachin: near Sadon, s. dat., Prain's Collector s.n. (K!).

Smilax jiankunii Li (1992: 21), syn. nov. Type:-CHINA. Yunnan: Gongshan Xian, Dulongjiang Valley, Meiliwang, 1800 m, 20 May 1991, Dulongjiang Bot. Expedition 6962 (holotype KUN!). Paratypes:-CHINA. Yunnan: Nanpula, 1300 m, Dulongjiang Bot. Expedition 4025 (KUN!), 6709 (KUN!); Bapou, Dulongjiang Bot. Expedition 4102 (KUN!), 4749 (KUN!); Mabidan, Dulongjiang Bot. Expedition 4073 (KUN!), 4625 (KUN!). 


\section{References}

Cameron, K.M. \& Fu, C.X. (2006) A nuclear rDNA phylogeny of Smilax (Smilacaceae). Aliso 22: 598-605.

Chen, S.Q. \& Koyama, T. (2000) Smilax. In: Wu, Z.Y. \& Raven, P.H. (eds.) Flora of China 24. Science Press, Beijing, and Missouri Botanical Garden Press, St. Louis, Missouri, pp. 96-115.

Elith, J., Phillips, S.J., Hastie, T., Dudík, M., Chee, Y.E. \& Yates, C.J. (2011) A statistical explanation of MaxEnt for ecologists. Diversity and Distributions 17: 43-57.

Judd, W.S. (1998) The Smilacaceae in the southeastern United States. Harvard Papers in Botany 3: 147-169.

Koyama, T. (1975) Smilacaceae. In: Smitinand, T. \& Larsen, K. (eds.) Flora of Thailand 2. The Forest Herbarium, Royal Forest Department, Bangkok, pp. 210-250.

Koyama, T. (1983) Smilacaceae. In: Leroy, J.-F. (ed.) Flore du Cambodge, du Laos et du Viêtnam 20. Muséum National d'Histoire Naturelle, Laboratoire de Phanérogamie, Paris, pp. 69-124.

Kunth, K.S. (1850) Enumeratio plantarum 5. Cotta, Stuttgart, 908 pp.

Li, H. (1992) New taxa of the genus Smilax from Dulongjiang. Acta Botanica Yunnanica 14(S5): 19-21.

Linnaeus, C. (1753) Species plantarum. Laurentius Salvius, Stockholm, 1200 pp.

Nguyên, T.H. (2007) Smilacaceae. In: National Center for Natural Science and Technology (ed.) Flora of Vietnam 8. Science and Technics Publishing House, Hanoi, pp. 388-454.

Prain, D. (1900) Some new plants from Eastern India. The Journal of the Asiatic Society of Bengal 69: 168-186.

Qi, Z.C., Li, P. \& Fu, C.X. (2013) New combinations and a new name in Smilax for species of Heterosmilax in Eastern and Southeast Asian Smilacaceae (Liliales). Phytotaxa 117: 58-60. http://dx.doi.org/10.11646/phytotaxa.117.2.4

Qi, Z.C., Li, P., Zhao, Y.P., Cameron, K.M. \& Fu, C.X. (2012) Molecular phylogeny and biogeography of Smilacaceae (Liliales), a cosmopolitan family of monocots. In: Botanical Society of America (ed.) Botany 2012: The next generation. Annual meeting of the Botanical Society of America. Columbus, Ohio, p. 197. Available from: http:// www.2012.botanyconference.org/engine/search/index.php?func=detail\&aid=441.Accessed 07 July 2013.

Wang, F.T. \& Tang, T. (1978) Heterosmilax. In: Wang, F.T., Tang, T., Chen, S.Q., Chang, C.Y., Dai, L.K., Liang, S.Y., Tang, Y.C., Liou, L. \& Lang K.Y. (eds.) Flora Reipublicae Popularis Sinicae 15. Science Press, Beijing, pp. 238245. 